\title{
Barries to Effective Listening of Company Leaders in Medan City
}

DOI: https://doi.org/10.47175/rissj.v1i2.54

\section{| Emilia Ramadhani ${ }^{1, *}$ | Dewi Kurniawati ${ }^{2}$ Dayana $^{3}$ |}

\author{
1,2,3 Department of \\ Communication, University of \\ Sumatera Utara, Medan, \\ Indonesia \\ *emilia.ramadhani@usu.ac.id
}

\begin{abstract}
Listening is as important as speaking or giving a speech to an audience. Very few leaders realize that conversation determines the growth and productivity of the organization / company they lead. Most people also believe that they have heard effectively in a conversation, which is one of the main elements in effective communication. This type of research was quantitative descriptive analysis. This research was conducted on the core implementers (managerial and executives from various divisions) from several companies or organizations in the city of Medan, as many as one hundred (100) respondents who worked in the fields of education, health, community service, law, hospitality, and entrepreneurship. Data collection techniques were carried out in two ways, namely by using a questionnaire and google form. Google form was used only for leaders who have very limited time because of their work. Then a short interview was conducted relating to the answers given. For data analysis, quantitative descriptive analysis techniques was used using figures or pictures showing the magnitude of the numbers or frequencies of the answers provided and followed by data reduction and drawing conclusions. The results showed that almost all respondents believed that they had heard effectively. But in reality this was not the case. Most leaders experienced personal interference where they always tried to be an entertainer when listening to the other person. As listeners, their minds were always preoccupied with finding ways to make the other person feel valued, happy and approved.

KEYWORDS

Leader's Organizational Communication; Leader's Effective Communication; Leader's Effective Listening
\end{abstract}

\section{INTRODUCTION}

Communication is closely related to the process of giving information and receiving feedback. The process of receiving feedback is the process of actively listening to what is conveyed by the recipient of information (our partner in communication). We always listen to something, but actively listening has a deeper depth of meaning than just hearing a series of words. This careful listening is what we call effective listening. This ability to listen effectively encourages good communication and at the same time minimizes misunderstanding.

Most people believe that they have listened effectively, which also makes it rare for people to consciously want to develop their abilities in this field. Not because this ability is difficult to learn, but most of us are raised in an environment that does not provide an effective listener's role model, so that effective listening behavior is something that must be learned seriously rather than done naturally.

Many researches has proven that, by listening effectively, we will get more information, build trust, reduce the likelihood of conflict, know in what way someone wants to be 
appreciated. Even further, by listening effectively, we are able to get a better understanding of what triggers an action or what inspires (motivation and fear) a person.

A study of 8,000 workers consisted of business people, hospital employees, teachers and government officials showed that they felt that thier communication was more effective than their subordinates/fostered (Haney, 1979). Meanwhile other research stated that the average person actually only heard $25 \%$ of what was actually delivered by the speaker (Husman et. al., 1988).

According to Lehman et. al., (1996) most managers spend their daily work listening and speaking with supervisors, employees, customers and various business associations. Listening is as important as speaking or giving a speech to an audience. We see so many company projects or programs stalled in the middle of the road just because of the discommunication of its members. Conversely, we can also witness an arena of office environment that can run beautifully because it has developed an elegant and productive communication process in it.

Words are not trivial matters, words are manifestations and symbols from our perspective, thoughts, perceptions, how we share these perceptions with others. Very few leaders realize that conversation determines the health and productivity of the organization (company) they lead. According to Bovee and John (2012: 66) listening is the most important skill needed to complete the work. Listening effectively strengthens organizational relationships, increases product delivery, prepares organizations for innovation opportunities, and allows them to manage in an era marked by increasing diversity in the workforce and customers served by the company. Effective listening is very important in the process of building trust not only between organizations, but also between individuals.

Seeing the importance of effective listening skills in an organization (company), researcher tries to analyze more deeply about the obstacles that affect one's ability to hear effectively in carrying out its functions in the organization (company), especially in the city of Medan. The problems in this study is to find out what are the barriers to effective listening that are found in leaders when conducting interpersonal communication within the organization (company)?

Furthermore, the research objectives aimed to find out the barriers to effective listening found in leaders when conducting interpersonal communication within the organization (company) and to classif the types of barriers to effective listening to facilitate the emergence of awareness when barriers arise in the process of communication (conversation) between personal leaders in the organization (company)

\section{RESEARCH METHODS}

\section{Research Design, Time and Location}

This type of research was quantitative descriptive analysis. The initial stage needed to conduct this research is to design a questionnaire that can uncover effective listening barriers that arise in the listener in the communication process.

This research has been conducted in July 2019 until October 2019, by taking the location of research in several agencies (companies) in the city of Medan engaged in government, education, health, telecommunications, ports, community services, finance, law, hospitality, hotel, boarding schools and entrepreneurs.

\section{Research Subjects}

The research subjects in this study were the core implementers of the organization (managerial and executives from various divisions), whose daily functions was to carry out the decision making and implementation of organizational policies to achieve the vision and 
mission of the organization. The informants in this study were the leaders starting from the level of Directors, Managerial, Head of Division, and Supervision from various Agencies (Companies) in the city of Medan, amounting to 100 people.

\section{Data Collection and Analysis Technique}

In this study, data collection techniques were carried out in two ways, namely by using a questionnaire and Google form. Google form was used only for leaders who have very limited time because of their work. Then a short interview was conducted relating to the answers given. For data analysis, quantitative descriptive analysis techniques was used using figures or pictures showing the magnitude of the numbers or frequencies of the answers provided and followed by data reduction and drawing conclusions.

\section{RESULTS AND DISCUSSION}

Based on data collection that has been carried out on 100 respondents, consisted of leaders of agencies/ companies from the level of Directors, managerial, heads of division and supervision, the following results were obtained.

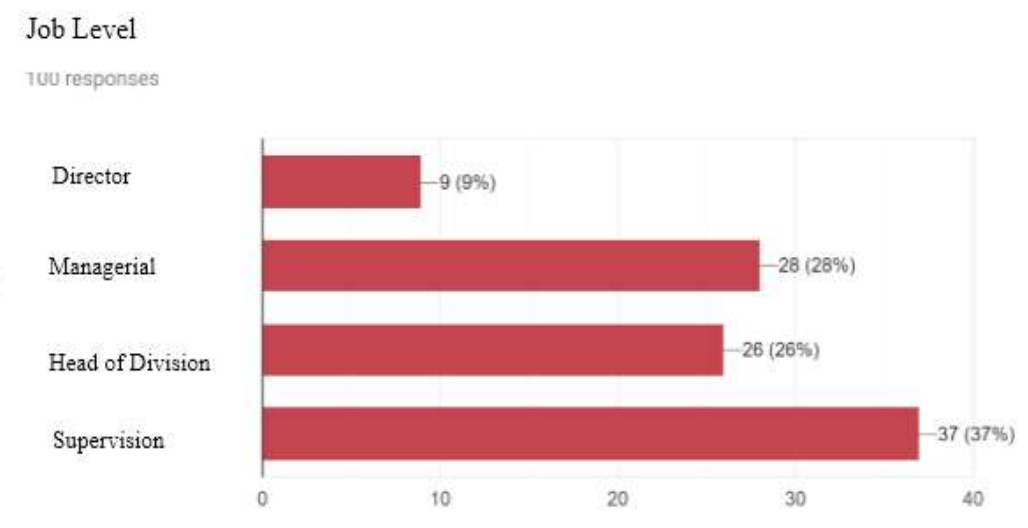

Figure 1. Job Level

Figure 1 shows that the majority of respondents were at the level of supervision. This showed that supervisory level leaders were easier to find and have more time compared to directors in this research process.

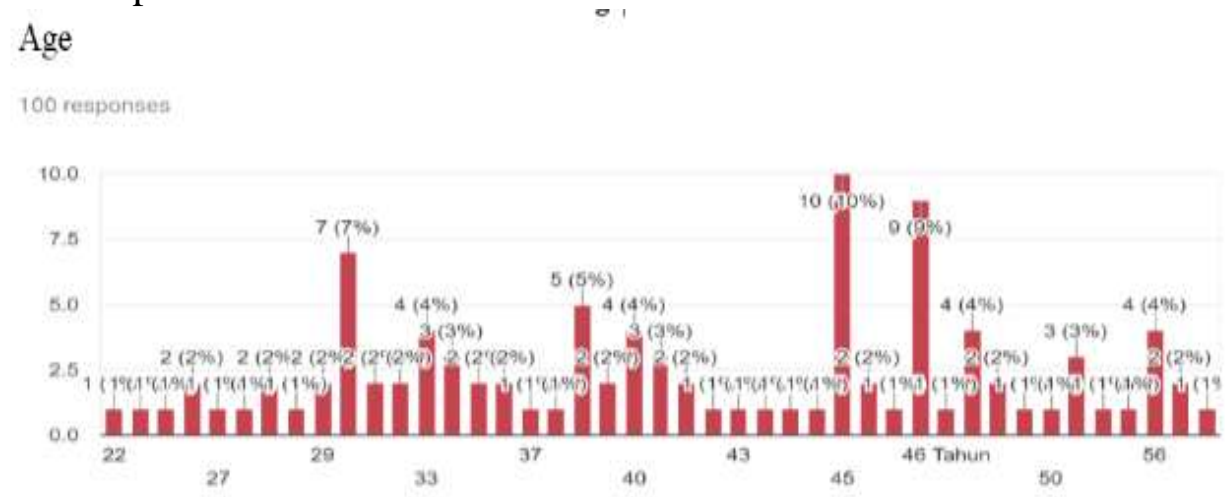

Figure 2. Age

From the Figure 2, it can be seen that the respondents' range of age was in the productive age of 45, 46 and 29 years according to the level of supervision in the company. Where time, energy and their minds are needed in the company. 
You intemupt, to straighten what is meant or to conect unconscions errors, logic flow, terms used, etc.

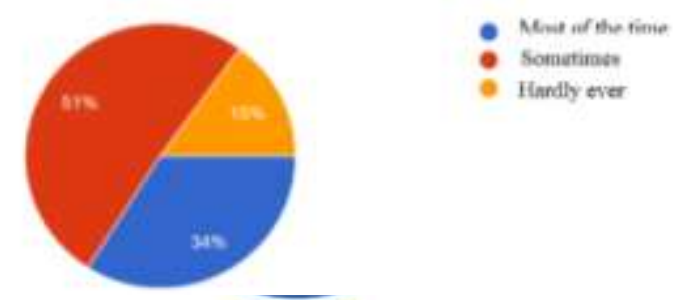

Figure 3. Gender

Furthermore, the Figure 3 shows that there are more male respondents than female respondents. This showed that for the leader level, men are more dominant than women.

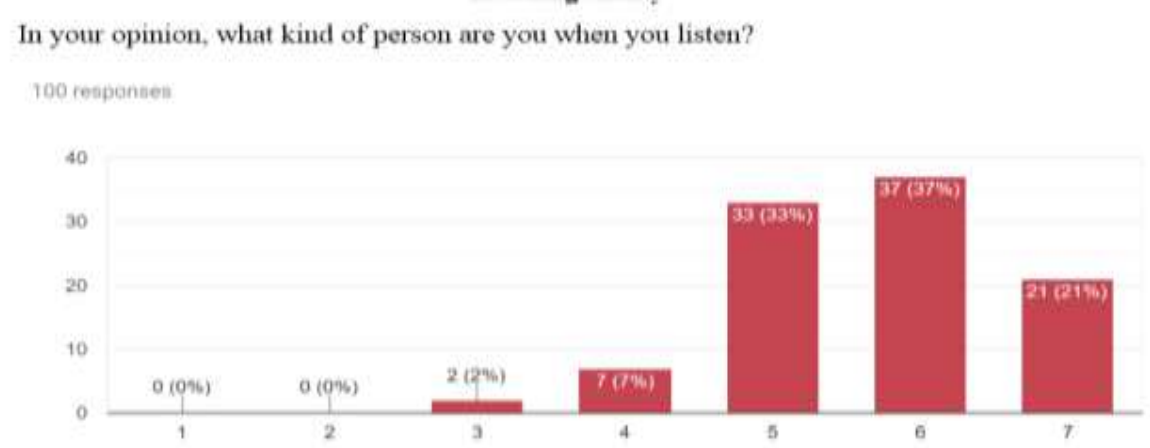

Figure 4. Listening Ability

It can be seen on the Figure 4 that almost all respondents stated that they were good (patient) listeners, at the level of 5,6, and 7 .

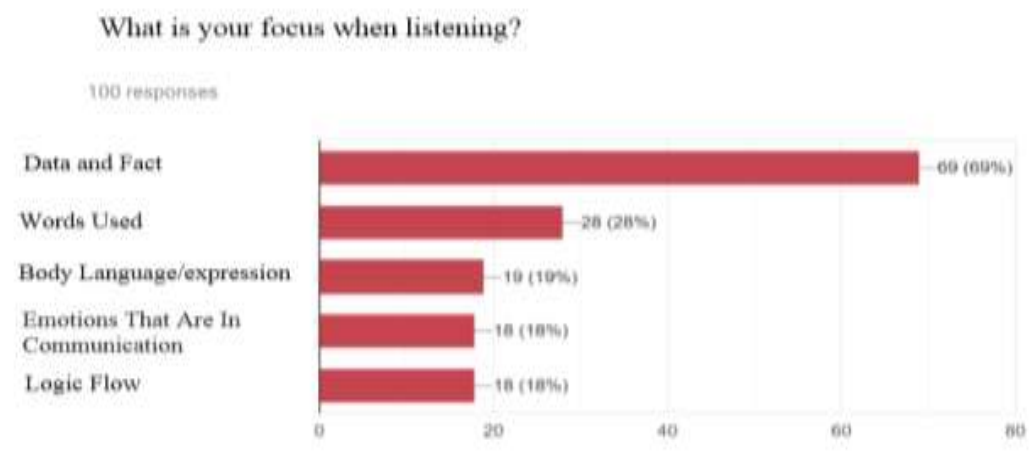

Figure 5. Focus When Listening

From the Figure 5, it can be seen that the majority of respondents' focus when listening was data and facts. This showed that the respondents were very careful about the contents of the message that were delivered.

Does your quality in listening depends on who you are talking to?

100 responses

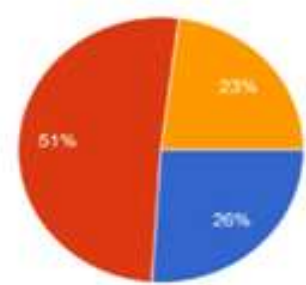

Most of the time
Sometimes

Hardly ever

Figure 6. Quality When Listening 
From the Figure 6, it can be seen that most of the respondents stated that the quality of their hearing occasionally depended on who was speaking.

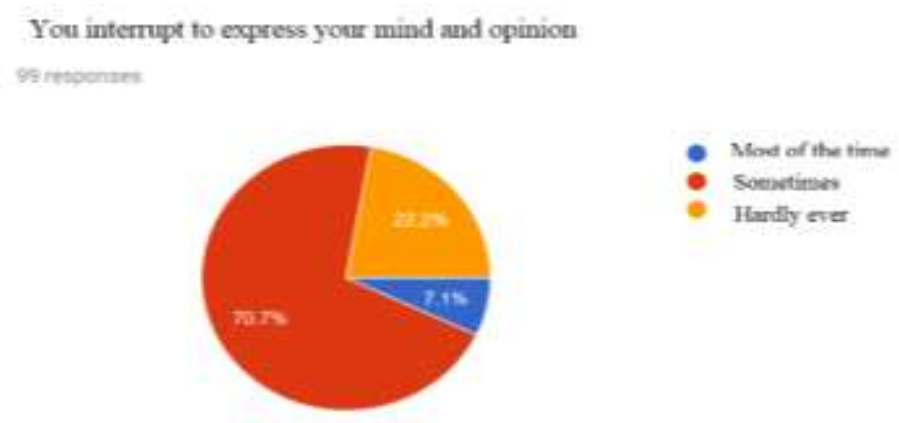

Figure 7. Ways to express thoughts and opinions

From the Figure 7 can be seen that most of the respondents have ever interrupt a conversation to express their thoughts and opinions.

You interupt to get clarification
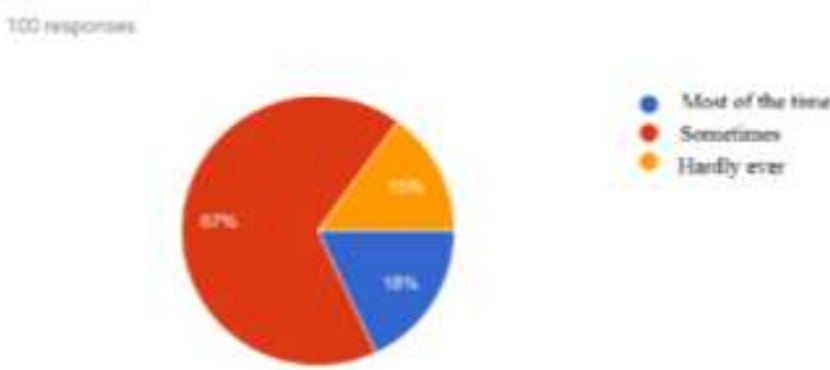

Figure 8. Ways to get clarification

From the Figure 8, it can be seen that most of the respondents have ever interrupted a conversation to get clarification.

You intemeyt, to straghten what is meant or to correct unconscions crors. logic flow, tems used, etc.
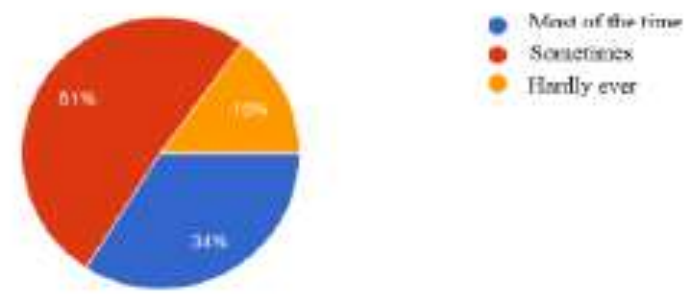

Figure 9. Ways to straighten what is meant

From the Figure 9, it can be seen that almost all of the respondents have ever interrupted a conversation to straighten what is meant by the speaker.

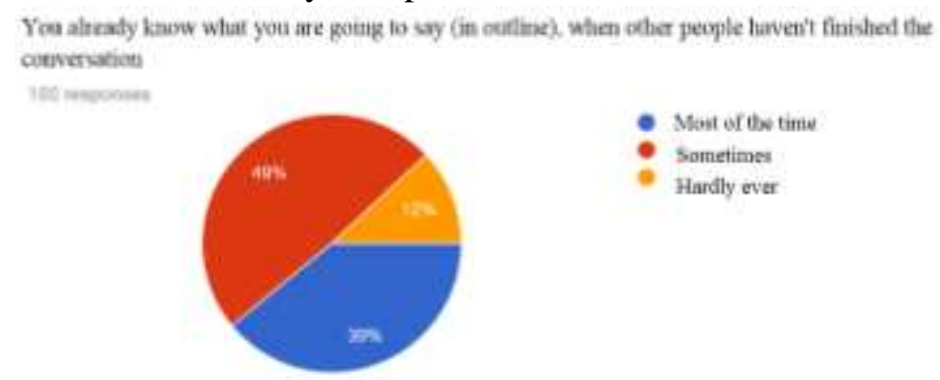

Figure 10. Reliable advisor 
From the figure 10, it can be seen that most respondents have made the mistake of trying to be a reliable advisor to the person they are talking to. Namely had the feeling of already knowing what to say even though other people haven't finished the conversation.

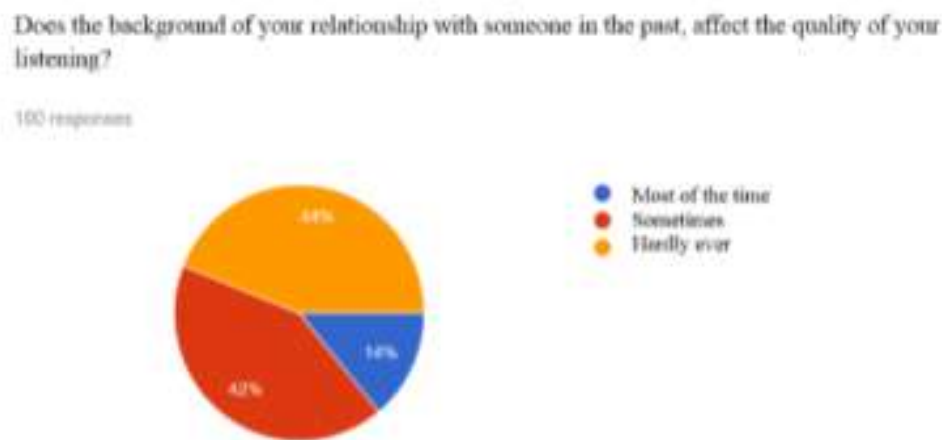

Figure 11. Making a comparison

From the Figure 11 it is known that the majority of respondents never made a comparison while listening (44\%) and some other, as much as $44 \%$, have ever made a comparison.

\footnotetext{
You are able to make forecasting assumptions about what the end of the conversation, the actual hidden intention to be conveyed, concluding before the speaker finishes
}

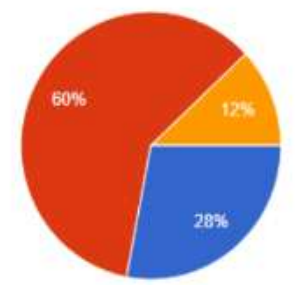

Most of the tim

Sometimes

Figure 12. Mind reading

From the Figure 12 it can be seen that the majority of respondents stated that they occasionally read the thoughts of their interlocutors by making forecast assumptions about the end of the conversation.

Your focus depends on the contents of the conversation, you can distinguish which is ingortant and which can be ignored
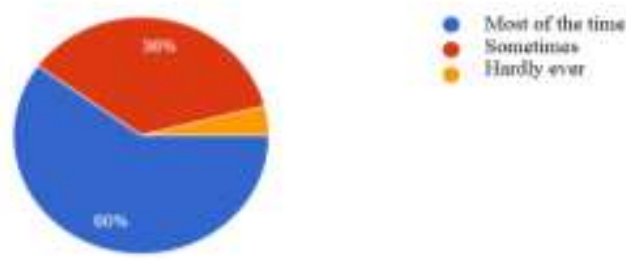

Figure 13. Filtering

From the Figure 13 it can be seen that most of the respondents stated that they almost always able to distinguish which was important and which things that can be ignored. 

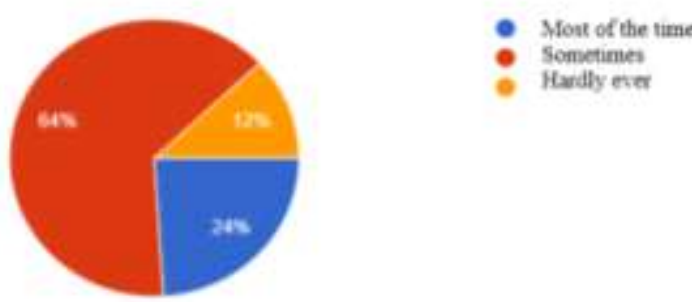

Figure 14. Self-Story

From the Figure 14 it can be seen that the majority of respondents stated that they were occasionally trapped in interruption of self-stories, that is, if there were words, sentences or events expressed by the speaker, and it triggered their memories and emotions about an event experienced either in the past or a possibility in the future, it then makes our mind float to that event / possibility.
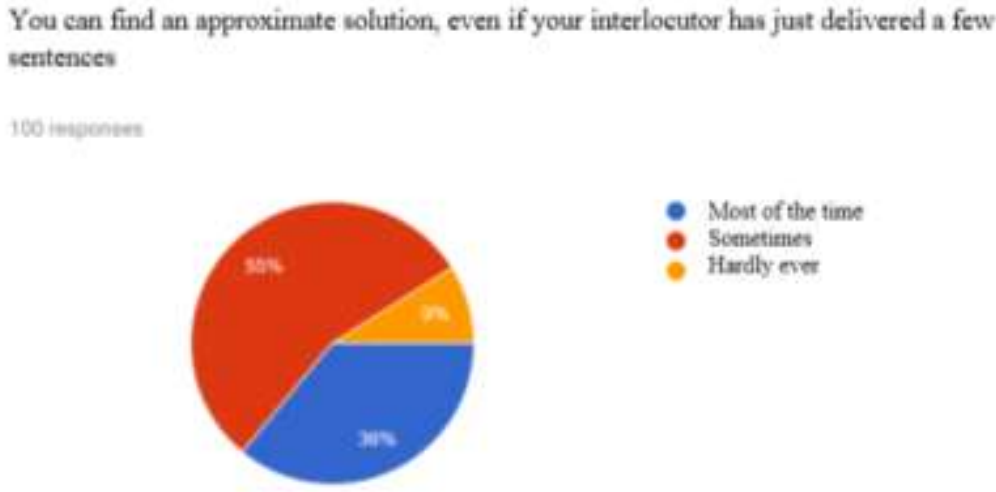

Figure 15. Becoming a reliable advisor

From the Figure 15, it can be seen that most of the respondents stated that they had (occasionally) become a reliable advisor to the interlocutors. Namely, had the feeling of able to find an approximate solution, even though someone else has just delivered a few sentences.

$$
\text { You try to make your listening activities make the other person feel valued, and heard }
$$

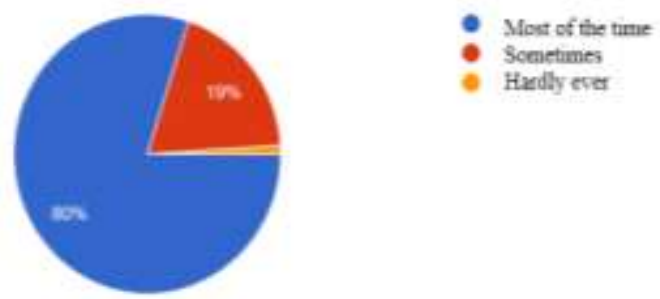

Figure 16. Becoming a comforter

From the Figure 16, it can be seen that some of the respondents stated that they were almost always becoming a comforter for their interlocutors. Where they tried to make their interlocutors feel valued and heard. 


\section{CONCLUSION}

Based on the research that has been done, it can be concluded that:

1. There are several personal barriers to effective listening found in leaders in the process of interpersonal communication in the organization (company), namely, barriers in measuring one's ability as an effective listener; barriers of desire to express thoughts, opinions or wishes for clarification; the barrier of feeling that you already know what to say even though the other person hasn't finished the conversation; barriers of disturbances from past events; barriers of making forecast predictions about what the ends of conversation; barriers of feeling able to find an approximate solution, even though someone else has just delivered a few sentences; and barriers in trying to make the other person feel valued and heard. But from some of these barriers, the biggest barrier in the leader is the desire to always try to be a comforter when listening to the speaker. As listeners, their minds are always preoccupied with finding ways to make the other person feel happy, appreciated, and heard. This happens because most of them, even us, were raised in an environment that does not provide an effective listener's role model, so that effective listening behavior is something that must be learned seriously rather than done naturally.

2. Barriers to effective listening found in this study can be classified as a form of barriers and disturbances that originate from within the leader, namely trying to be a reliable advisor, trying to read the mind of the other person, often trapped in a self -story, trying to become a reliable advisor, and always trying to be a comforter for the interlocutor. But there are some advantages found in the leaders in this research, namely they always focus on listening by giving priority to facts and data from the information provided; never make comparisons of things that have passed and have the ability to filter information well, by receiving important information and ignoring information that is considered not important.

There is also a solution that can be given in the form of recommendations for conducting effective listening training at the level of leaders in the company. Training is considered important because words are not trivial matters, words are manifestations and symbols from our perspective, thoughts, perceptions, the way we share these perceptions with others. Very few leaders realize that conversation determines the health and productivity of the organization (company) they lead, the diversity of the workforce and the customers the company serves. Effective listening is very important in the process of building trust not only between organizations, but also between individuals.

\section{REFERENCES}

Bovee Courtland L,. Thill, John V,. (2012). Business Communication. PT. Indeks. $9^{\text {th }}$ edition. San Diego.

Dilts, Robert, (2003). From coach to awakener. Meta Publications. Capitola, California 95010.

Effendi, Onong Uchjana. (2001). Ilmu komunikasi teori dan praktek, PT. Remaja Rosdakarya. Bandung.

Haney, W.V., (1979). Communication and interpersonal relations. Homewood, Illinois: Richard D, Irwin. Inc

Hardjana, A, (2000), Audit komunikasi teori dan praktek, Grasindo. Jakarta.

Husein, Umar. (2008). Desain penelitian msdm dan perilaku karyawan, seri desain penelitian bisnis no. 1, PT. Rajagrafindo Persada. Jakarta.

Huseman, R. C., Lahiff, James, M., \& Penrose, John, M. (1988). Business communication: Strategies and skills, Dryden Press, South Western College Publishing. Chicago.

Lehman, C., Himstreet, W., Baty, Wayne. (1996). Business Communications, South Western Collegen Publishing. Ohio, $11^{\text {th }}$ Edition. 